\title{
Effect of Bacterial Endophytes Lysinibacillus sp. on Plant Growth and Fruit Yield of Tomato (Solanum lycopersicum)
}

\author{
Pramod Kumar Sahu ${ }^{1,2 *}$, M.K. Shivaprakash ${ }^{1}$, B.C. Mallesha ${ }^{1}$, \\ C.T. Subbarayappa ${ }^{3}$ and G.P. Brahmaprakash ${ }^{1 *}$
}

\begin{abstract}
${ }^{1}$ Deparment of Agricultural Microbiology, ${ }^{3}$ Deparment of Soil Science and Agricultural Chemistry, University of Agricultural Sciences, GKVK, Bengaluru-560065, Karnataka, India ${ }^{2}$ ICAR-National Bureau of Agriculturally Important Microorganisms, Kushmaur, Maunath Bhanjan, UP-275103, India
\end{abstract}

*Corresponding author

\section{A B S T R A C T}

\section{Keywords}

Endophyte bacteria, fruit yield, Lysinibacillus sp. isolate $1 \mathrm{TH} 16 \mathrm{a}$,

Phosphate solubilization, IAA production

Article Info

Accepted:

22 April 2018

Available Online:

10 May 2018
Endophytes are known for its novel metabolites and benefits for host. Diversified role of endophytes are being studied in order to enhance their use in agriculture production system. Endophytes are being use for plant growth promotion, alleviation of biotic and abiotic stresses, enhancing agronomic traits, etc. In this study, bacterial endophytes isolated from earlier studies were tested for its plant growth promoting traits in tomato. Bacterial endophytes were tested for plant growth promoting attributes like phosphate solubilization and IAA production. These endophytes were inoculated to tomato plants in pot trial and their effect on dry matter accumulation and fruit yield were recorded. Results indicated that the endophyte 1TH16a had performed well in pot trial and significantly enhanced fruit yield as compare to control. Significantly higher root and shoot biomass were recorded from strain 1TH16a and 1016. Molecular identification using 16s rRNA shows its identity to Lysinibacillus sp. This strain is having potential plant growth promoting traits and detailed study is needed for its commercial use in tomato and other crops.

\section{Introduction}

The realm of ecofriendly agriculture has been flourishing with potential alternatives of harmful agrochemicals in last few decades. Microbes with tremendous capacities of PGPR, biocontrol and abiotic stress alleviation are being explored in rhizosphere, endosphere, phyllosphere and unique ecological niches (Abbamondi et al., 2016). Endophytes have proven potential to be used in agriculture. Bacterial endophytes are present in different plant parts and impart beneficial effects on its host plant (Lodewyckx et al., 2002). 
Endophytes are the microorganisms which live inside the host and do not result in any significant loss of performance to it. Bacterial endophytes confers large array of advantages to its host plant like nitrogen fixation, mineral solubilization, siderophore, phytohormone, 1aminocyclopropane-1-carboxylic acid (ACC) deaminase, secondary metabolites, enzymes, antibiotics, induce systemic resistance and tolerance, etc. (Lodewyckx et al., 2002; Sahu et al., 2016). Endophytes are reported to enhance performance of other beneficial microbes also like Rhizobium (Bai et al., 2003). Endophytic inoculants are reported to solubilize mineral nutrients in the rhizosphere (Otieno et al., 2015). This enhances the performance of crop as well as reduces necessity of adding higher amount of chemical fertilizers. Phytohormones control the physiology and performance of plants and endophytes enhances plant growth by controlling these phytohormone levels in the plant (Khan et al., 2013; Szilagyi-Zecchin et al., 2014). Therefore, it is a good strategy to screen for phytohormone producing bacterial endophyte for enhanced growth of plants.

Beneficial impact of bacterial endophytes has been reported from several crops like rice (Rho et al., 2018), wheat (Herrera et al., 2016), legumes (Bai et al., 2003), cotton (Zhou, 2015), maize (Gond et al., 2015), flowers (Engel et al., 2016), sugarcane (Aguiar et al., 2016), vegetables (Xie et al., 2016), fruits (Kannan et al., 2015), etc. Tomato is the commercial crop grown across the globe and India is the second largest producer of it (Saxena et al., 2016). There are several microbial inoculants tested for its growth and development (Abbamondi et al., 2016).

Enhancement of fruit yield and quality is important for the tomato farmers. Exploring endophytic treasure for plant growth promotion and fruit yield is required to sustainably boost agriculture production system. Endophytes can also be screened for its capacity to enhance fruit yield of tomato. This study was conducted to screen and evaluate bacterial endophytes for their plant growth promotion attribute. Screening was targeted for enhanced dry matter partitioning after vegetative growth.

\section{Materials and Methods}

\section{Bacterial strain and growth media}

The endophytic bacterial cultures from earlier studies and rhizospheric strains were taken from NAIMCC, ICAR-NBAIM, Mau. Six bacterial cultures were taken for this study (four endophytes 1TH16a, 4PH5a, 8PR3 and 8PH9) and two rhizospheric bacteria (1016 and 342). The mother cultures were stored in glycerol stock. Nutrient agar slants premonitored for purity was used for short term preservation till the study completed. Cultures of each microorganism were inoculated and grown for a period of 24 hours in nutrient broth. This active culture was used for inoculation to tomato plants.

\section{Mineral phosphate solubilization}

Phosphate solubilization by bacterial endophytes was tested in Pikovskaya's agar medium (Pikovskaya, 1948). Actively grown culture was spotted on Pikovskaya's agar medium and incubated at $28^{\circ} \mathrm{C}$ for 3-4 days. Development of a clear halo around the spotted colony indicates phosphate solubilization.

\section{Production of IAA}

Indole acetic acid (IAA) production was assessed in Luria bertani (LB) broth with and without $5 \mu \mathrm{g} / \mathrm{ml}$ tryptophan. Inoculation was done in $15 \mathrm{ml} \mathrm{LB}$ broth and incubated at $28^{\circ} \mathrm{C}$ for 4-5 days. After this period, cultures were 
centrifuged for $10 \mathrm{~min}$ at 5000 RPM. In $10 \mathrm{ml}$ supernatant, two drops orthophosphoric acid and $5 \mathrm{ml}$ Salkowski's reagent were mixed. (Salkowski's reagent $=50 \mathrm{ml}, 35 \%$ perchloric acid $+1 \mathrm{ml} 0.5 \mathrm{FeCl}_{3}$ ). Intensity of pink color developed indicated production of IAA (Patten and Glick, 1996).

\section{Pot trial}

Forty five days old tomato seedlings (Variety S-22) were used for transplanting. Plastic pots were filled with four $\mathrm{kgs}$ of autoclaved soil. Seedling roots were dipped in bacterial suspension containing $0.5 \%$ carboxy methyl cellulose (CMC) as sticking agent. Roots were dipped for a period of 10 minutes and planted in pots. Plants were watered based on moisture depletion in the pots. Observations were taken after 4 months of transplanting. Root biomass, shoot biomass and fruit weight were taken as key features of biomass accumulation. Samples are dried in oven at $60^{\circ} \mathrm{C}$ and it got stable weight in 5 days of drying.

\section{Identification of prominent endophyte}

Endophyte 1TH16a was found to have prominent effects on biomass accumulation and fruit yield. 1TH16a culture is grown for 24 hours in nutrient agar plate pre-monitored for its purity from any contamination. A loopful of this culture is taken for DNA isolation. DNA was extracted by ZR fungal/bacterial DNA Mini Prep ${ }^{\mathrm{TM}}$ kit for isolating genomic DNA (ZYMO Research Corporation, USA). DNA was isolated as per manufacturer's instruction and stored at -20 ${ }^{\circ} \mathrm{C}$. Molecular identification was done by $16 \mathrm{~s}$ rRNA partial sequencing. DNA from 1TH16a was amplified by universal $16 \mathrm{~S}$ rRNA primers 27 forward (5'-AGAGTTTGATCCTGG CTCAG-3') and 1492 reverse (5'TACGGYTACCTTGTTACGACTT-3'). PCR conditions were same as Thomas et al., (2008). Purified PCR products were sent to
M/s Eurofins for 16s rRNA partial sequencing. The obtained sequence was trimmed for poor sequence reads and identity was matched in EZbiocloud database (https://www.ezbiocloud.net) and NCBI. Sequence was submitted to NCBI- BankIt database. Phylogenetic relatedness of $1 \mathrm{TH} 16 \mathrm{a}$ with other close relatives was assessed using neighbor joining method and tree was developed using MEGA7 (version=7.0.25).

\section{Statistical analysis}

This experiment was conducted in randomized complete block design (RCBD) with seven treatments and three replications each. Comparison has been done based on standard deviation values and means were separated by DMRT.

\section{Results and Discussion}

Exploration for better microbial isolates is a continuous process. Screening could bring potential strains for field application. In this study, most potent endophyte was Lysinibacillus sp. strain 1TH16a. Lysinibacillus sp. is reported as potent plant growth promoter by several workers in other crops (Sgroy et al., 2009; Andrade et al., 2014).

\section{Phosphorus solubilization}

Isolates had shown variable phosphate solubilizing potential in pikowskaya's medium (Table 1). Highest P-solubilization was recorded from 1TH16a and 8PH9. Isolate 8PR3 gave poor $\mathrm{P}$ solubilization. There is good number of reports indicating $P$ solubilization by bacterial endophytes. The findings are corresponding to reports of Venden et al., (2010) and Naureen et al., (2017) where Lysinibacillus sp. had been reported as potential P-solubilizer. 


\section{Production of IAA}

IAA production was highest in 1016 and 1TH16a (Table 1). 4PH5a had given low IAA production. Endophytes are known for their phytohormone production. The current findings are in line with results of Kuklinskysobral et al., (2004) which show IAA production as chief function trait for plant growth promotion by bacterial endophytes. They have also indicated that $69 \%$ of their endophytes showing IAA production and Psolubilization, had capability of fixing dinitrogen. The screening based on these two features is in line with approaches chosen by other workers for plant growth promotion (Kuklinsky-sobral et al., 2004; Andrade et al., 2014).

\section{Pot trial}

Shoot dry weight was recorded significantly higher in the plants treated with 1TH16a, 342, $8 \mathrm{PR} 3$ and $8 \mathrm{PH} 3$ whereas other treatments were recorded lower shoot dry weight (Fig. 1, Table 2). Shoot dry weight also included dry weight of its fruits (Fig. 2 and Table 2). Root dry weight was highest in 1016, 1TH16a and 8PH9 inoculated plants whereas other treatments were recorded lower root dry weight (Fig. 3 and Table 2).

Fresh weight of fruits was highest in 1TH16a inoculated plants (Fig. 4). Plants inoculated with isolate 342 and 8PR3 were also having significantly higher fruit weight than control. Lowest fresh fruit weight was recorded from control, 1016, 4PH5a and 8PH9 plants. Root to shoot ratio was lowest in 1TH16a, 342 and 8PR3 inoculated plants.

Identification based on 16s rRNA had shown highest similarity with Lysinibacillus sp. with $100 \%$ query cover. The sequence was submitted to NCBI with accession number MH194246 (Fig. 5).
Higher biomass accumulation by inoculation of Lysinibacilus sp. in this experiment is supported by the findings of Sgroy et al., (2009) which reports Lysinibacillus as producer of phytohormones and nitrogen fixer. Enhanced shoot and root biomass may also be due to the phosphate solubilizing ability of the endophytes. It might be secreting some of the compounds which helped in mineral nutrient solubilization and then uptake. Application of P-solubilizing microorganism was reported to enhance plant growth, biomass and dry matter partitioning in plants (Bagyaraj and Krishnaraj, 2000; Sahu et al., 2016). Enhanced dry matter accumulation might be due to the high nutrient availability to the plants. Phosphorus nutrition is also important for initial plant growth and strength. Initial strength of the plant translates further to robust development of plant. This is in line with the results of Andrade et al., (2014). They had reported presence of nifH gene in Lysinibacillus sp. which could enhance the nitrogen nutrition and biomass accumulation in the plant. They have also reported high solubilization index for tricalcium phosphate in Lysinibacillus sp.

Plants inoculated with isolate 342, 8PR3 and 8PH9 had relatively better shoot biomass content but less was translated into fruit yield as compared to $1 \mathrm{TH} 16 \mathrm{a}$. This might be due to better phytohormone induction by 1TH16a for fruit bearing as compared to others (Ali et al., 2017). Enhanced nutrient uptake also supports higher fruit bearing. Higher fruit yield in 1TH16a might be due to its ability to enhance nutrient uptake. Phytohormone production by bacterial endophytes is also a key reason for enhanced fruit yield. The results are supported by the findings of Ali and co-workers (2017).

Some of the indirect effects by microbial inoculants were also reported to influence growth by influencing phytohormone level in plants (Singh 2013). 
Table.1 Assessment of biocontrol and plant growth promoting traits in bacterial endophytes

\begin{tabular}{|l|l|l|l|}
\hline Sn. & Isolates & $\begin{array}{l}\text { Phosphate } \\
\text { solubilizati } \\
\text { on }\end{array}$ & $\begin{array}{l}\text { IAA } \\
\text { production }\end{array}$ \\
\hline 1. & 1016 & + & ++ \\
\hline 2. & $1 \mathrm{TH} 16 \mathrm{a}$ & +++ & ++ \\
\hline 3. & 342 & + & + \\
\hline 4. & 4 PH5a & + & - \\
\hline 5.5 & $8 \mathrm{PR} 3$ & - & + \\
\hline 6. & $8 \mathrm{PH} 9$ & ++ & + \\
\hline
\end{tabular}

+++ Prominent activity; ++ Moderate activity; + low activity; - no activity

Table.2 Plant biomass by inoculation of endophytic bacteria

\begin{tabular}{|l|l|l|l|l|l|}
\hline Sn. & Isolates & $\begin{array}{l}\text { Shoot } \\
\text { dry } \\
\text { weight }\end{array}$ & $\begin{array}{l}\text { Root dry } \\
\text { weight }\end{array}$ & $\begin{array}{l}\text { Fresh } \\
\text { fruit } \\
\text { weight }\end{array}$ & R:S ratio \\
\hline 1. & Control & $13.60^{\mathrm{d}}$ & $4.70^{\mathrm{c}}$ & $56.97^{\mathrm{de}}$ & $0.35^{\mathrm{bc}}$ \\
\hline 2. & 1016 & $11.52^{\mathrm{d}}$ & $6.48^{\mathrm{a}}$ & $47.40^{\mathrm{e}}$ & $0.56^{\mathrm{a}}$ \\
\hline 3. & $1 \mathrm{TH} 16 \mathrm{a}$ & $23.60^{\mathrm{a}}$ & $6.33^{\mathrm{ab}}$ & $152.81^{\mathrm{a}}$ & $0.27^{\mathrm{c}}$ \\
\hline 4. & 342 & $20.39^{\mathrm{b}}$ & $5.44^{\mathrm{bc}}$ & $75.00^{\mathrm{c}}$ & $0.27^{\mathrm{c}}$ \\
\hline 5. & 4PH5a & $13.58^{\mathrm{d}}$ & $5.30^{\mathrm{bc}}$ & $57.44^{\mathrm{de}}$ & $0.39^{\mathrm{b}}$ \\
\hline 6. & 8PR3 & $19.83^{\mathrm{b}}$ & $5.30^{\mathrm{bc}}$ & $89.89^{\mathrm{b}}$ & $0.27^{\mathrm{c}}$ \\
\hline 7. & 8PH9 & $17.40^{\mathrm{c}}$ & $5.94^{\mathrm{ab}}$ & $61.33^{\mathrm{d}}$ & $0.34^{\mathrm{bc}}$ \\
\hline & SEm \pm & 0.68 & 0.31 & 3.28 & 0.03 \\
\hline
\end{tabular}

Fig.1 Tomato plants indicating effects of 1TH16a inoculation on (A) plant growth and (B) fruit yield

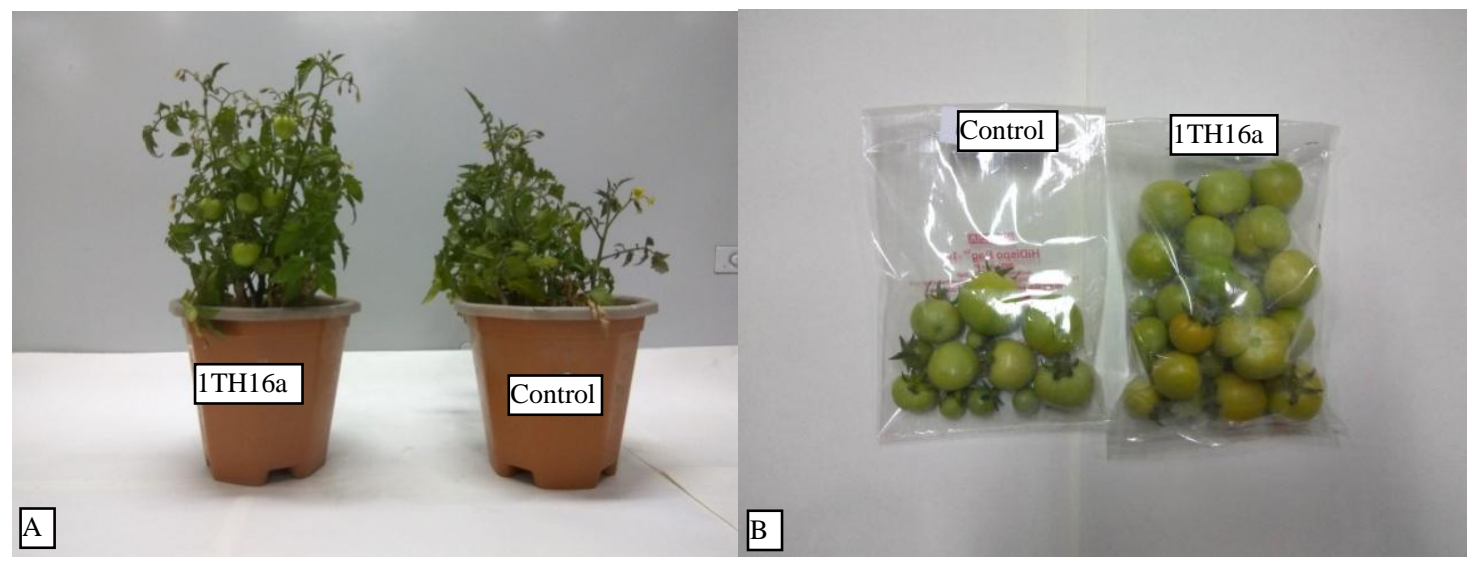


Fig.2 Effect of endophyte inoculation on shoot dry weight

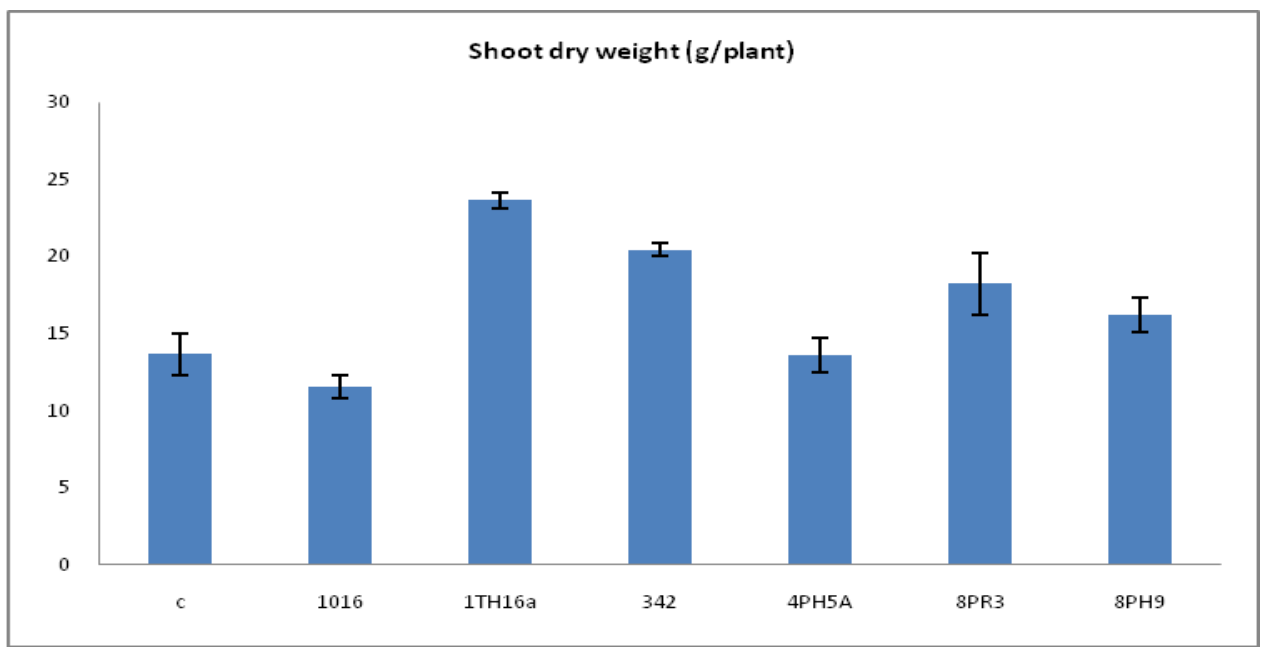

Fig.3 Effect of endophyte inoculation on root dry weight

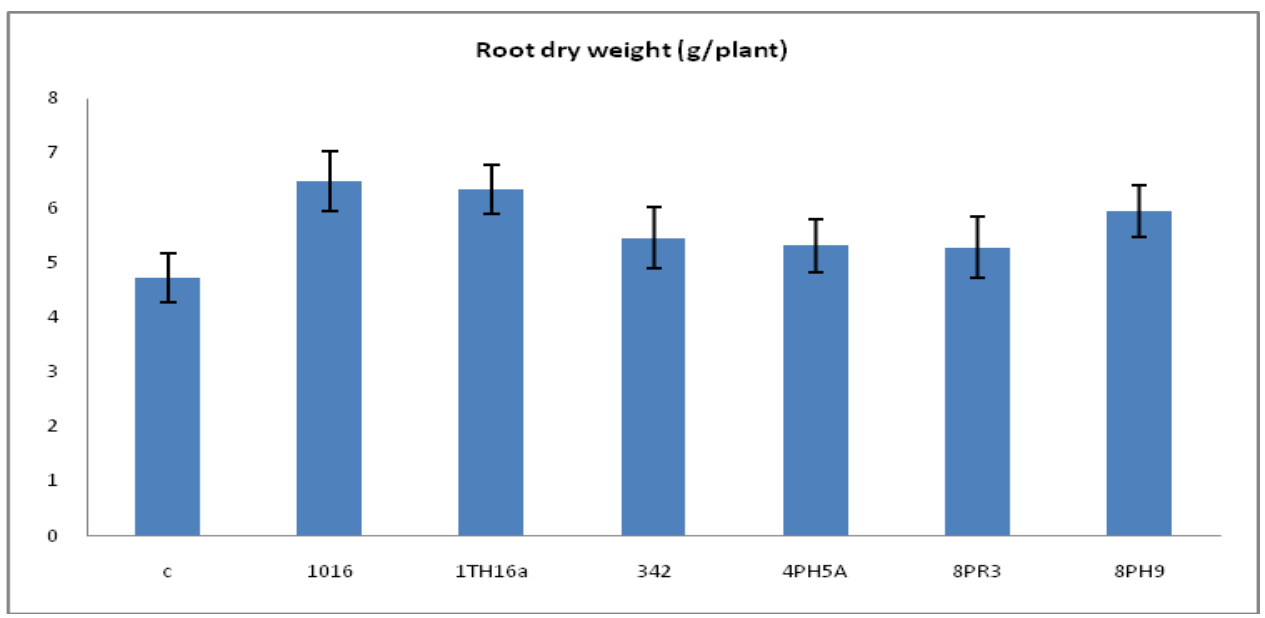

Fig.4 Effect of endophyte inoculation on fresh fruit weight

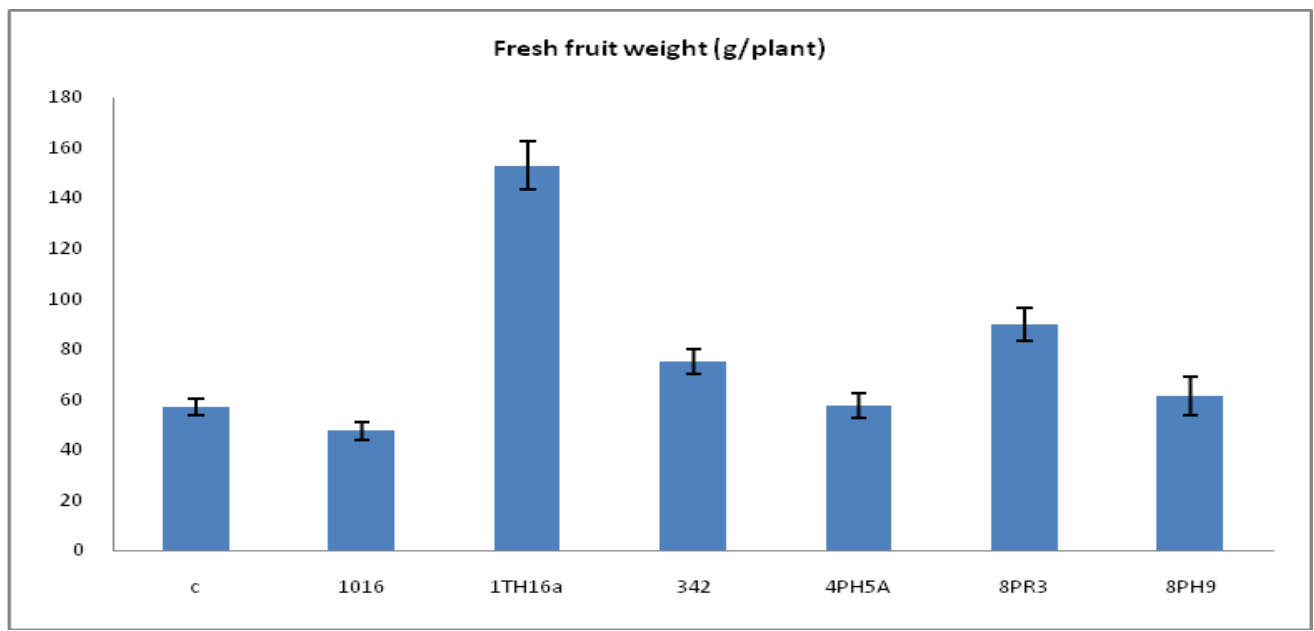


Fig.5 Phylogenetic tree indicating the relatedness of MH194246 Lysinibacillus sp. 1TH16a with other close relatives



This might be one of the reasons for higher biomass accumulation in plants. Venden and co-workers (2010) has reported higher solubilization of mineral phosphate and production of higher amount of IAA by Lysinibacillus sp. which contributed to higher plant growth in ginseng.

Zhang et al., (2010) reported that Lysinibacillus sp. also has the ability to protect plants from pathogens. This could be an additional mechanism which might be contributing towards higher crop yield in tomato by Lysinibacillus sp. 1TH16a inoculation. Verma and co-workers (2014) reported that Lysinibacillus sp. also solubilize zinc and produce ACC-deaminase which might be reducing the ethylene stress in the plants and helping it in realizing higher fruit yield and biomass accumulation. Yadav and co-workers (2016) assessed the IAA production capabilities of different isolates and found that Lysinibacilus fusiformis strain
IARI-AR8 produces higher amount of IAA even at adverse conditions (higher $\mathrm{pH}$ 8-10).

Naureen et al., (2017) had studied Lysinibacillus sphaericus ZA9 in greater detail and shown its potential for plant growth promotion and biotic stress management. They indicated production of higher quantity of IAA $(697 \mu \mathrm{g} / \mathrm{ml})$, siderophore, hydrolytic enzymes and HCN. This bacterium had shown potential solubilization of phosphorus, potassium and silicon. They had shown enhanced shoot growth in tomato and cucumber due to application of this bacterium. It is also reported to produce 2pentyl-4-quinolinecarboxylic acid and 1methyl cyclohexene which are strong antagonist to most of the fungi. There are several such reports indicating potential of Lysinibacillus sp. for plant growth promotion like phosphate solubilization and phytohormone production (Hardoim et al., 2008). These could be the reasons for 
enhanced the fruit yield by inoculation of Lysinibacillus sp. strain 1TH16a in tomato.

This strain of Lysinibacillus has potential to be used as inoculant for plant growth promotion in tomato. Other mechanisms of Lysinibacillus sp. and its interaction with plant need to be unravel so as to harness more for enhancing agriculture production. Experiments are also needed to standardize delivery technique and formulation for its field application. Further, extensive trials are needed to utilize the potential of Lysinibacillus sp. strain 1TH16a to be used as inoculant for tomato and other crops.

\section{Acknowledgement}

The authors gratefully acknowledge UAS, GKVK, Bengaluru and ICAR-NBAIM, Mau for conducting experiments and financial support extended during these experiments.

\section{References}

Abbamondi, G.R., Tommonaro, G., Weyens, N., Thijs, S., Sillen, W., Gkorezis, P., Iodice, C., de Melo Rangel, W., Nicolaus, B. and Vangronsveld, J., 2016. Plant growth-promoting effects of rhizospheric and endophytic bacteria associated with different tomato cultivars and new tomato hybrids. Chemical and Biological Technologies in Agriculture. 3(1):1.

Aguiar, N.O., Medici, L.O., Olivares, F.L., Dobbss, L.B., Torres- Netto, A., Silva, S.F., Novotny, E.H. and Canellas, L.P., 2016. Metabolic profile and antioxidant responses during drought stress recovery in sugarcane treated with humic acids and endophytic diazotrophic bacteria. Annals of applied biology. 168(2): 203-213.

Ali, S., Charles, T.C. and Glick, B.R., 2017. Endophytic phytohormones and their role in plant growth promotion. In Functional Importance of the Plant Microbiome (pp. 89-105). Springer, Cham.

Andrade, L.F., de Souza, G.L.O.D., Nietsche, S., Xavier, A.A., Costa, M.R., Cardoso, A.M.S., Pereira, M.C.T. and Pereira, D.F.G.S., 2014. Analysis of the abilities of endophytic bacteria associated with banana tree roots to promote plant growth. Journal of Microbiology. 52(1), pp.27-34.

Bagyaraj, D. J. and Krishnaraj, P. U., 2000, Mineral phosphate solubilization: Agronomic implications and mechanisms. Proc. Indian Natn. Sci. Acad. 66: 69-82.

Bai, Y., Zhou, X., Smith, D.L., 2003. Crop ecology, management and quality. Enhanced soybean plant growth resulting from coinoculation of Bacillus strains with Bradyrhizobium japonicum. Crop Sci. 43: 1774- 1781.

Engel, R., Szabó, K., Abrankó, L., Rendes, K., Füzy, A. and Takács, T., 2016. Effect of arbuscular mycorrhizal fungi on the growth and polyphenol profile of marjoram, lemon balm, and marigold. Journal of agricultural and food chemistry. 64(19): 3733-3742.

Gond, S.K., Bergen, M.S., Torres, M.S. and White Jr, J.F., 2015. Endophytic Bacillus spp. produce antifungal lipopeptides and induce host defence gene expression in maize. Microbiol Res. 172:79-87.

Hardoim, P.R., van Overbeek, L.S. and van Elsas, J.D., 2008. Properties of bacterial endophytes and their proposed role in plant growth. Trends in Microbiology. 16(10): 463-471.

Herrera, S.D., Grossi, C., Zawoznik, M. and Groppa, M.D., 2016. Wheat seeds harbour bacterial endophytes with potential as plant growth promoters and biocontrol agents of Fusarium 
graminearum. Microbiological research. 186: 37-43.

Kannan, R., Damodaran, T. and Umamaheswari, S., 2015. Sodicity tolerant polyembryonic mango root stock plants: A putative role of endophytic bacteria. African Journal of Biotechnology. 14(4): 350-359.

Khan, A.L., Waqas, M., Hamayun, M., et al., (2013). Co-synergism of endophyte Penicillium resedanum LK6 with salicylic acid helped Capsicum annuиm in biomass recovery and osmotic stress mitigation. BMC Microbiol. 3(1):51.

Kuklinsky- Sobral, J., Araújo, W.L., Mendes, R., Geraldi, I.O., Pizzirani- Kleiner, A.A. and Azevedo, J.L., 2004. Isolation and characterization of soybean- associated bacteria and their potential for plant growth promotion. Environmental Microbiology. 6(12): 1244-1251.

Lodewyckx, C., Vangronsveld, J., Porteous, F., Moore, E.R., Taghavi, S., Mezgeay, M. and der Lelie, D.V., 2002. Endophytic bacteria and their potential applications. Critical Reviews in Plant Sciences. 21(6): 583-606.

Naureen, Z., Rehman, N.U., Hussain, H., Hussain, J., Gilani, S.A., Al Housni, S.K., Mabood, F., Khan, A.L., Farooq, S., Abbas, G. and Harrasi, A.A., 2017. Exploring the potentials of Lysinibacillus sphaericus ZA9 for plant growth promotion and biocontrol activities against phytopathogenic fungi. Frontiers in microbiology. 8: 1477.

Otieno, N., Lally, R.D., Kiwanuka, S., Lloyd, A., Ryan, D., Germaine, K.J. and Dowling, D.N., 2015. Plant growth promotion induced by phosphate solubilizing endophytic Pseudomonas isolates. Frontiers in Microbiology. 6:745.
Patten, C.L., Glick, B.R., 1996. Bacterial biosynthesis of indole-3-acetic acid. Can J Microbiol. 42(3):207-220.

Pikovskaya, R.I., 1948. Mobilization of phosphates in soil in connection with the vital activities of some microbial species. Mikrobiologia. 17:362-370.

Rho, H., Van Epps, V., Wegley, N., Doty, S.L. and Kim, S.H., 2018. Salicaceae Endophytes Modulate Stomatal Behavior and Increase Water Use Efficiency in Rice. Frontiers in plant science. 9:188

Sahu, P.K., Lavanya, G., Gupta, A. and Brahmaprakash, G.P., 2016. Fluid bed dried microbial consortium for enhanced plant growth: A step towards next generation bioformulation. Vegetos. 29(4): 6-10.

Saxena, M., Bhatacharya, S., Malhotra, S.K., 2016. Horticulture Statistics at a Glance 2015. Ministry of Agriculture \& Farmers Welfare, Government of India. nhb.gov.in/statistics/Publication/hortstat _glance.pdf

Sgroy, V., Cassán, F., Masciarelli, O., Del Papa, M.F., Lagares, A. and Luna, V., 2009. Isolation and characterization of endophytic plant growth-promoting (PGPB) or stress homeostasisregulating (PSHB) bacteria associated to the halophyte Prosopis strombulifera. Applied microbiology and Biotechnology. 85(2): 371-381.

Singh, J.S., 2013. Plant growth promoting rhizobacteria potential microbes for sustainable agriculture. Resonance. 18: 275.

Szilagyi-Zecchin, V.J., Ikeda, A.C., Hungria, M., et al., 2014. Identification and characterization of endophytic bacteria from corn (Zea mays L.) roots with biotechnological potential in agriculture. AMB Express. 4: 26

Thomas, P., Swarna, G.K., Roy, P.K., Patil, P., 2008. Identification of culturable and 
originally non-culturable endophytic bacteria isolated from shoot tip cultures of banana cv. Grand Naine. Plant Cell, Tissue and Organ Culture. 93(1): 55.

Vendan, R.T., Yu, Y.J., Lee, S.H. and Rhee, Y.H., 2010. Diversity of endophytic bacteria in ginseng and their potential for plant growth promotion. The Journal of Microbiology, 48(5): 559-565.

Verma, P., Yadav, A.N., Kazy, S.K., Saxena, A.K. and Suman, A., 2014. Evaluating the diversity and phylogeny of plant growth promoting bacteria associated with wheat (Triticum aestivum) growing in central zone of India. Int J Curr Microbiol Appl Sci. 3(5): 432-447.

Xie, L., Usui, E. and Narisawa, K., 2016. A endophytic fungus, Ramichloridium cerophilum, promotes growth of a nonmycorrhizal plant, Chinese cabbage. African Journal of Biotechnology: 15(25): 1299-1305.
Yadav, A.N., Sachan, S.G., Verma, P. and Saxena, A.K., 2016. Bioprospecting of plant growth promoting psychrotrophic Bacilli from the cold desert of north western Indian Himalayas.

Zhang, S., White, T.L., Martinez, M.C., McInroy, J.A., Kloepper, J.W. and Klassen, W., 2010. Evaluation of plant growth-promoting rhizobacteria for control of Phytophthora blight on squash under greenhouse conditions. Biological Control, 53(1), pp.129-135.

Zhou, W., 2015. Fungal Endophytes and Their Ecological Roles in Cotton: Evaluation of Potential Antagonistic Activity against Plant Parasitic Nematodes and Insect Herbivores (Doctoral dissertation) Texas A\&M University.

\section{How to cite this article:}

Pramod Kumar Sahu, M.K. Shivaprakash, B.C. Mallesha, C.T. Subbarayappa and Brahmaprakash, G.P. 2018. Effect of Bacterial Endophytes Lysinibacillus sp. on Plant Growth and Fruit Yield of Tomato (Solanum lycopersicum). Int.J.Curr.Microbiol.App.Sci. 7(05): 33993408. doi: https://doi.org/10.20546/ijcmas.2018.705.397 